\title{
Assessing North Carolina School Administration Candidates Using an Integrated Standards-Based Portfolio
}

\author{
William M. Gummerson \\ Appalachian State University, Boone, North Carolina
}

\begin{abstract}
North Carolina's educational leadership programs for Masters of School Administration (MSA) and Add-on-Licensure (AOL) candidates recently completed a mandated "revisioning" process based on the North Carolina Standards for School Executives. As part of that process the MSA/AOL portfolio replaced the School Leaders Licensure Assessment (SLLA) that was previously required. In light of the national debate on the preparation of school principals and North Carolina's adoption of new leadership standards, this article discusses the portfolio's integration with those standards, university leadership programs, and research on student achievement. Ultimately, that integration strengthens the portfolio's value as a tool for developing leaders who can improve student achievement. In turn, the leadership and student achievement data acquired during the principal evaluation process can be used in the future to improve leadership standards, university leadership programs, and the portfolio assessment itself.
\end{abstract}

\section{Introduction}

For six decades a national debate in the United States has raged over how universities should produce effective school leaders and how states should license their school principals [1]. During that time several academic, national, and state organizations proposed national standards [2]. Among others, these included: the National Council for the Accreditation of Teacher Education (NCATE) (1954), the Committee for the Advancement of School Administration (CASA) (1955), the National Policy Board for Educational Administration (NPBEA) (1988), the Interstate Leaders Licensure Consortium (ISLLC) (1994), the Council for Chief State School Officers (CCSSO) (1996), and the Educational Leadership Constituent Council (ELCC) (2002). By 2010, NCATE completed a merger with the Teacher Education Accreditation Council (TEAC) to form a single Council for the Accreditation of Educator
Preparation (CAEP). Central to the debate was the relative value of theory and practice, as well as what role federal, state, and local agencies should play in the education and licensing of educational leaders at the school level.

In the United States, which lacks a national educational system, states have the authority under Article $\mathrm{X}$ of the United States Constitution to establish their own public educational systems. To this day, suspicions of allowing the federal government power at the expense of individual states and their citizens have repeatedly thwarted the development of common leadership standards acceptable to all fifty states. In the 1990's, however, North Carolina and 23 other states under the auspices of the Council of Chief State School Officers (CSSO) voluntarily adopted the Interstate Leaders Licensure Consortium (ISLLC) standards for school leaders. Having found a major void in the area of school leadership, the authors of ISLLC hoped their standards would provide "the best avenue to allow diverse stakeholders to drive improvement efforts along a wide variety of fronts-licensure, program approval, and candidate assessment” [3].

\section{The School Leaders Licensure Assessment}

In 1998, CSSO, its member states, and the Educational Testing Service (ETS) developed the School Leaders Licensure Assessment (SLLA). The SLLA is an instrument used to measure a candidate's understanding of how to apply the ISLLC standards to situations that principals commonly encounter. Candidates are required to demonstrate best practices based upon their skills and knowledge. The test is "purposefully designed to differentiate between competent and less than competent school principals.” It, however, cannot be used to predict the performance of future principals [4]. Test-takers devise solutions to vignettes of school situations and respond to documents commonly addressed by school principals. They are required to evaluate actions, synthesize information, and solve problems. The design of the test allows candidates to 
demonstrate their ability to handle difficult problems, which can easily be transferred to the principalship. The SLLA is intended to provide a common measure of the readiness of prospective candidates to become principals as well as to establish reciprocity of licensure among states that adopt the assessment. Only 5 states originally adopted the assessment as a measure for licensure. Currently 18 of the fifty states and the U.S. Virgin Islands require the test for principal licensure. Why not more?

Despite 46 states having either adopted or used the ISLLC standards to create their own, the SLLA has suffered several criticisms. Critics have disparaged the test for accepting answers that "promote a new administrative discourse that banishes complexity, conflict, and critical reflection" [5]. Test-takers are not required to indicate knowledge of professional literature. Interpreting whether an answer accepted as correct demonstrates what is in the best interests of the child is thought to be a difficult if not subjective process for scorers. Some wonder if too much emphasis on a high stakes test will result in "either a significant narrowing of the curriculum or test-preparation clinics springing up, or both" [6]. It has been suggested that states that adopt the SLLA as part of their screening process for administrators are in effect narrowing their selection primarily to candidates who are familiar with the ISLLC standards.

\section{North Carolina's 21st Standards}

Following passage of the federal No Child Left Behind Act (NCLB) in 2001, states faced the real possibility of either being sanctioned or losing federal dollars for state public school systems if their students did not meet negotiated academic standards. Research studies have asserted increasingly that student achievement is either directly or indirectly linked to school leadership [7]. Additionally, it was thought that to develop better principals, leadership candidates needed to be exposed to more intensive problem based learning and internships that provide an authentic experience, something that the SLLA could not duplicate. Sensing that the North Carolina public educational system would not be able to sustain the necessary rate of improvement, meet the mandates of NCLB, or prepare students for an increasingly interconnected global economy, the state decided to establish new leadership standards. By 2006, a 21st Century Standards Framework emphasizing the need for all students to be able to compete in a global economy was adopted. Schools were to be led by 21st Century professionals capable of applying innovation. Furthermore, university leadership programs and school leaders were to be guided by an integrated set of reforms that "revisioned" the standards for leadership programs and principal candidates. An evaluation instrument based upon the same standards was to be employed once candidates became principals in the schools.

In the place of the ISLLC leadership standards the state elected to adopt seven standards for critical leadership based on Making Sense of Leading Schools: A Study of the Principalship [8]. While the ISLLC standards emphasize what principals ought to do, the Making Sense study promotes leadership focusing on seven areas and activities, based upon what principals actually do. The principal is expected to be a master diagnostician, discerning when, how, and with whom to share leadership responsibilities. The seven responsibilities of leadership include: instructional, cultural, managerial, human resource, strategic, external development, and micropolitical leadership. These seven areas and activities are the basis for the North Carolina Standards for School Executives, which provide guidelines as to what principals should do to be effective leaders in public schools [9]. The Executive Standards include summaries, practices, and artifacts. Summaries define the nature and purpose of the standards. Practices describe observable leadership actions. Artifacts provide evidence of the standards being applied in the school setting.

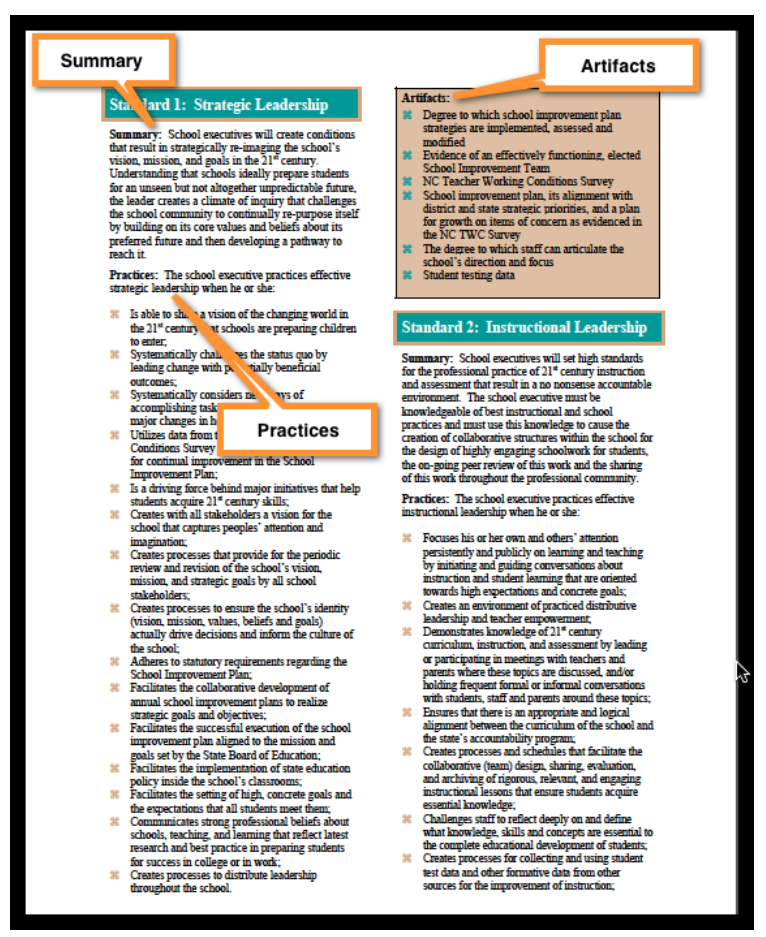

Figure 1. North Carolina Standards for School Executives. Standard 1: Strategic Leadership, [Summary, Practices, and Artifacts]

To ensure that university programs are aligned with the North Carolina Standards for School Executives, the state, with the help of the Mid- 
continent Education Research Laboratory (McRel), created a North Carolina School Executive Evaluation Rubric for Preservice Candidates [10]. Additionally, McRel developed the North Carolina School Executive: Principal and Assistant Principal Evaluation Process, similarly linking the Executive Standards to their research on balanced leadership and student achievement [11].

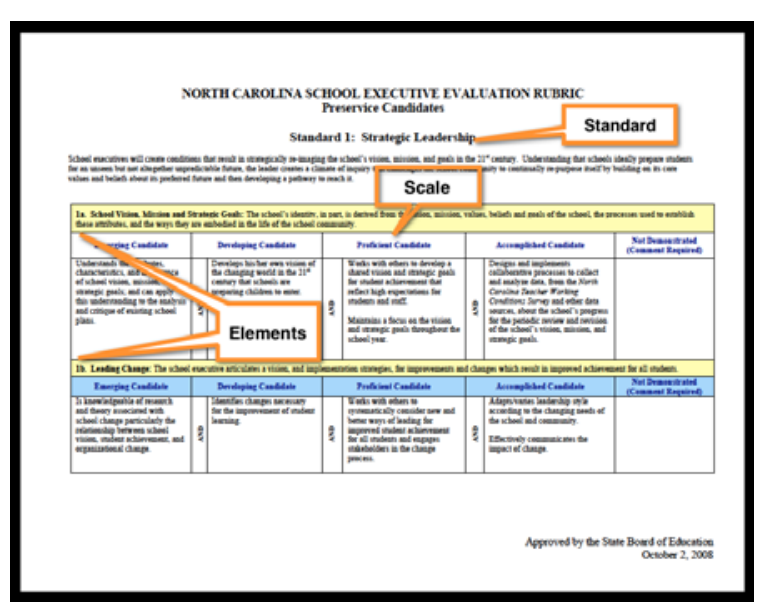

Figure 2. North Carolina School Executive Evaluation Rubric for Preservice Candidates. Standard 1: Strategic Leadership, [Standard, Scale, and Elements]

University leadership programs were required to "revision" themselves by integrating the North Carolina Standards for School Executives into their course of studies, expanding partnerships with public schools, and designing a portfolio aligned to those standards. An assessment portfolio based upon the Evaluation Rubric for Preservice candidates and tailored to each university's leadership program is now the vehicle used by principal candidates to demonstrate their ability to apply "training to actual school needs and challenges” [12].

\section{The New MSA/AOL Portfolio at Appalachian State University}

Elizabeth Jones identifies six reasons why a portfolio can be a powerful tool for professional development [13]. Students learn to integrate theory and practice; meta-cognition and self-reflection are fostered; students learn to identify the gap between current practice and standard practice; a bridge between the discourse of academia and practice can be established; and, the portfolio serves as a powerful formative and summative instrument. The portfolio for MSA/AOL candidates at Appalachian State University was designed considering each of these factors. The format of the portfolio follows the North Carolina School Executive Evaluation Rubric for Preservice Candidates, which is aligned with the seven critical leadership standards from the North Carolina Standards for School Executives. Each standard includes leadership elements that an effective principal must address if he or she is to promote student success. Strategic Leadership involves developing a school vision, mission, and strategic goals, as well as leading change, developing a school improvement plan, and when appropriate, distributing leadership. Instructional Leadership focuses on learning, teaching, curriculum, instruction, assessment, and instructional time. Cultural Leadership emphasizes establishing a collaborative work environment, incorporating school culture and identity, acknowledging failures, and celebrating accomplishments. Building efficacy and empowerment among the staff is of equal value. Human Resource Leadership recognizes the importance of professional learning communities and the recruiting, hiring, placing, and mentoring of staff. Teacher evaluation is considered to be of paramount importance. Managerial Leadership monitors school resources and the budget. Conflict management and resolution, systematic communication, and high expectations for students and staff are priorities. External Leadership development promotes parent and community involvement, outreach, and oversight of federal, state, and district mandates. Micropolitical Leadership pays significant attention to the internal and external political forces that affect a school.

The Appalachian State University portfolio is both formative and summative in design. In contrast to the SLLA, which in many respects provides only a snapshot in time, the formative nature of the prerequisite coursework for the portfolio allows for adaptation and growth by both professors and principal candidates. Students are able to examine their personal methodology for learning and hone their leadership skills over time. Professors are able to more effectively measure student growth, and, based upon the successes or failures of students, can modify coursework and the kinds of leadership experiences candidates are exposed to during the internship. During the coursework phase of the leadership program, students conduct an environmental scan of a school, create and establish a mock budget to be presented to a school board, brief educational law cases, and assess school programs and school improvement plans. William James Popham has characterized formative assessment as a means to transform learning into a more realistic and authentic process. "What a teacher wants students to acquire when mastering a cognitive skill is an understanding of how the skill works and an ability to discern for themselves whether they are satisfactorily employing the skill that is being taught” [14]. 
The portfolio is intended to provide MSA/AOL candidates with a means to demonstrate the knowledge and skills acquired during their academic coursework and the internship. The portfolio consists of six evidence clusters that demonstrate a candidate's ability to solve authentic leadership problems that a principal routinely addresses as the leader of a school. The university, however, defines the nature and scope of the six evidence clusters that students must provide in their portfolio. Using schools of their choosing, MSA/AOL candidates work with principals, teachers, and students in the school, along with community members, to devise a plan to solve each problem.

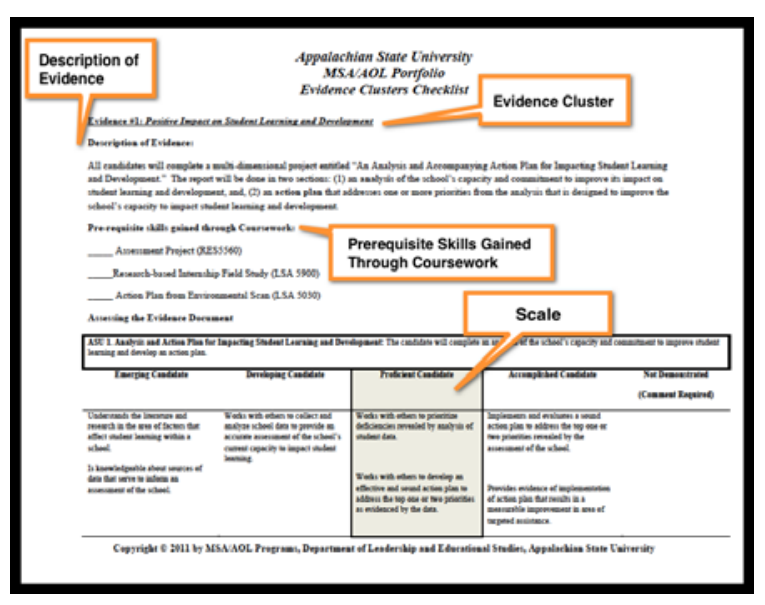

Figure 3: Appalachian State University MSA/AOL Portfolio Evidence Clusters Checklist. Evidence Cluster 1: Positive Impact on Student Learning and Development, [Description of Evidence, Evidence Cluster, Prerequisite Skills Gained, and Scale]

Evidence Cluster 1 requires principal candidates to complete a multi-dimensional project entitled "An Analysis and Accompanying Action Plan for Impacting Student Learning and Development”. The analysis must address a school's capacity and commitment to improve student learning and development, as well as determine the priorities needed to accomplish the plan. Similarly, Evidence Cluster 2 is a multi-dimensional project culminating in "An Analysis and Action plan for School Capacity Building” in the area of teacher empowerment and leadership. Evidence Cluster 3, “An Assessment Project for School Community Building” focuses on improving a school's capacity to harness its community partners to promote student success. Using data and examples, candidates prepare a report that supports the school's community outreach agenda. "Assessing/Auditing a School's Organization and Management Procedures”, the requirement for Evidence Cluster 4, examines how effectively a school manages its support for improving student success. The project for Evidence Cluster 5 determines whether or not a school is promoting safe conditions and meeting the differentiated needs of students based on the school's culture and ethnic composition. Finally, working with a school and its community, candidates complete Evidence Cluster 6; an assessment of how well a school addresses systematic school improvement.

Although the Evidence Clusters in the Appalachian State University MSA/AOL portfolio are aligned with the Standards for School Executives and the Rubric for Preservice Candidates, the standards and elements from each are intentionally dispersed throughout the clusters. This is purposefully done to expose candidates to the authentic application of the standards and practices. Rarely, if ever, does a leader have the luxury of stopping time, placing multiple problems to the side, so that he or she can focus on a single problem. More than often, a principal is forced to deal with many problems that intersect or overlap. Consequently, an effective principal must be able to identify and apply multiple standards and practices simultaneously. The MSA/AOL portfolio provides an opportunity for candidates to experience this prior to assuming the challenges of the principalship.

When completed, each of the action plans is placed into TK-20, an electronic portfolio for grading. Using a Likert scale that is similar to the one employed in the Executive Preservice Rubric and the North Carolina Principal Evaluation Process, the candidate's performance is rated as Emerging, Developing, Proficient, Accomplished, or Not Demonstrated. Throughout the portfolio process, classroom professors, internship advisors, and supervising principals work closely with students in their assigned cohorts. The intent of the portfolio process is to develop master diagnosticians who can think, collaborate, and practice shared leadershiphallmarks in the Making Sense study.

\section{Evaluating the Effectiveness of the MSA/AOL Portfolio Assessment}

While the SLLA has been criticized for not being capable of predicting who will be an effective school leader, it has been determined to be a valid and reliable instrument for identifying candidates who can successfully apply the ISSLC standards. As an instrument for assessing future principals, will the MSA/AOL portfolio fare better? With regards to authentic assessment, the portfolio should be quite effective because it is purposeful, contains structured and unstructured elements, has a defined scoring scale, and promotes deep self-reflection. In the words of Elizabeth Jones (2010), the portfolio also has the added advantage of being a bridge between 
"the discourse of academia and the discourse of practice”. The alignment of the portfolio with the standards and elements contained in the Executive Rubric for Preservice Candidates which mirrors the North Carolina Standards for School Executives, will enhance the portfolio's content validity because both "are fairly representative of the universe of facts in the field covered” [15]. Linkage to the seven areas and activities of leadership from the Making Sense study, the basis for the North Carolina Standards for School Executives, will enhance content reliability, the degree to which "the assessment instrument contains the necessary procedures to truly measure its intended purpose” [16]. Results on interrater reliability will probably be mixed. While using criteria from the Rubric for Preservice Candidates as the standard for scoring will aid in the reliability of the instrument, the effectiveness of scoring will be diminished somewhat because evaluators will grade the portfolio holistically rather than by individual elements. Holistic scoring will save time during the assessment process but diminish interrater reliability that would have been enhanced if evaluators worked together to grade elements one at a time [17]. The MSA/AOL portfolio and its precursor, the SLLA, equally suffer from a lack of predictive validity because neither can infer whether or not an MSA/AOL candidate or a former test taker will become an effective principal. This is because a post-programmatic or post-test assessment of principals cannot include participants who do not become principals. Their absence from either assessment will skew the numbers and invalidate the final results.

\section{Developing Leaders that Promote Student Achievement}

Collectively, the alignment of the Standards for School Executives, the Executive Rubric for Preservice Candidates, the Principal Evaluation Process, and the portfolio will provide North Carolina with a wonderful opportunity to determine if "revisioned" leadership programs are producing effective principals capable of promoting student achievement in public schools. This is because the design of the Executive Rubric for Preservice Candidates and the Principal Evaluation Process is based on comprehensive research linking leadership to student achievement. The McRel Corporation, whose research provides the foundation for the two instruments, was heavily involved in their creation and the subsequent training of principals on how to apply their research to leadership in the schools. Using a meta-analysis of 70 studies selected out of over 5,000, the McRel researchers discovered a positive correlation (.25) between principals who properly managed 21 leadership responsibilities and student achievement. Principals who are aware of these responsibilities and the importance of the focus and the magnitude of change in their schools can positively affect student achievement significantly [18]. To educate principals how to incorporate this research into their daily leadership activities McRel developed a Balanced Leadership Framework. That framework emphasizes the importance of developing a purposeful school community, which focuses on school practices, classroom practices, and the student. Particular attention is paid to the magnitude of change, which requires the principal to create demand, implement change, manage transitions, and monitor and evaluate the process. By 2014, the North Carolina Principal Evaluation Process will include information on the progress of student achievement as part of the evaluation of every public school principal in North Carolina. The significance should not be lost. When this occurs, not only will North Carolina be able to determine the impact of principal leadership on improving student achievement; it will also be possible for the state to evaluate the effectiveness of the portfolio assessment, university leadership programs, and the leadership standards themselves. The unique integration and alignment of North Carolina's leadership standards, university leadership programs, the Rubric for Preservice Candidates and the North Carolina Principal Evaluation Process, based on a meta-analysis of research on leadership and student achievement, will make this possible.

Policy makers and practitioners, however, must be careful that student achievement scores "should become only part of an overall comprehensive plan" to evaluate leadership and teaching [19]. Whatever assessments are used for leadership, teaching, or the measuring of student achievement, to be considered reliable and valid, each must take into account other factors such as differing student and school characteristics, student mobility, influences inside and outside of the school, and poor curricular alignment.

\section{Conclusion}

North Carolina's decision to link common standards to the assessment of its leadership programs, leadership candidates, and principals is rare in the United States. While many states have used the ISLLC standards as a basis for their school leadership programs of study, their evaluation instruments for principals are not necessarily grounded in their state leadership standards or linked to university leadership programs of study. The "revisioning" of North Carolina's university programs and the abandonment of the SLLA in favor of a portfolio assessment is intended to promote a balance between leadership theory and practice. It is 
a by-product of the lengthy national debate over how best to prepare effective school leaders. Most promising is North Carolina's decision to ground its leadership standards in seasoned research linking them to the improvement of student academic achievement based upon the McRel studies on balanced leadership and the Portin study on what principals actually do on a daily basis in their schools. While the state of North Carolina has completed a validation study on the state's principal evaluation process, entitled Final Report: Development, Field Test, And Validation Of The North Carolina Educator Evaluation System (2011), there is still a need for the North Carolina School Executive Evaluation Rubric for Preservice Candidates that is used to evaluate leadership candidates to be validated [20]. This is because the Executive Preservice Rubric is based upon a blending of the seven standards of leadership from the Portin study and the 21 leadership responsibilities for student achievement advocated by the McRel study on balanced leadership.

The North Carolina School Executive: Principal and Assistant Principal Evaluation Process will, after 2014, provide a substantial amount of information on whether or not principals are improving student achievement. That information can eventually be used to promote the on-going assessment and revision of university programs, as well as assessment instruments and processes used to evaluate leadership candidates and principals. To be reliable and valid, such an assessment will have to take into account school and student characteristics that impact student learning and the assessment process.

\section{Acknowledgements}

Thanks to colleagues Drs. Barbara Howard, Precious Mudiwa, Al Profitt, Barbara Todd, Phyllis Tallent, George Olson, Stephen White, and David Hostetler for their friendships and insights. A special thanks is offered to Dr. Ken Jenkins, the chief architect and driving force behind the Appalachian State University portfolio and revisioning process.

\section{References}

[1] K.M. Brown, "Universities, Preparation of Educational Leaders", in The Encyclopedia of Educational Leadership and Administration, from http://www.sagepub.com/home. nav, 2006. (Access date: 8 September 2010).

[2] J.R. Hoyle, "Leadership National Standards", in The Encyclopedia of Educational Leadership and Administration, from http://www.sagepub.com/home.nav, 2006. (Access date: 15 September 2010).
[3] Shipman, N., and J. Murphy, The Interstate School Leaders Licensure Consortium (ISLLC) Standards for School Leaders, Council of Chief State School Officers, Washington DC, 1996.

[4] C.M. Reese, and R.J. Tannenbaum, "Gathering Content-related Validity Evidence for the School Leaders Licensure Assessment”, Journal of Personnel Evaluation in Education, Kluwer, Boston, MA, 1999, pp. 263-282.

[5] G.L. Anderson, "A Critique of the Test for School Leaders", Educational Leadership, Department of Supervision and Curriculum Development, N.E.A, Washington DC, 2000, pp. 67-70.

[6] L. Wildman, "How Adequate Are the ISLLC Standards and the Educational Testing Service's School Leaders Licensure Assessment?", edited by Carr, C.S., and C.I. Fulmer, in Educational Leadership: Knowing the Way, Showing the Way, Going the Way, Scarecrow Education, Oxford, UK, 2004, pp. 60-71.

[7] B. Witziers, R. Bosker, and M. Kruger, "Educational Leadership and Student Achievement: The Elusive Search for an Association", Educational Administration Quarterly, Sage Publications, Thousand Oaks, CA, 2003, pp. 389-425.

[8] Portin, B., P. Schneider, M. DeArmond, and L. Gundlach, Making Sense of Leading Schools: A Study of the Principalship, Center on Reinventing Public Education, University of Washington, 2003.

[9] North Carolina State Board of Education, SBE Highlights: Notes on the State Board of Education, from http://www.ncpublicschools.org/docs/stateboard/highlights /2006/11highlights.pdf, November 1-2, 2006. (Access date: 20 August 2010).

[10] North Carolina State Board of Education, SBE Highlights, from http://www.ncpublicschools.org/state board/highlights/2008/09highlights, September 9-11, 2008. (Access date: 21 August 2010).

[11] McREL, and North Carolina State Board of Education/Department of Public Instruction, North Carolina School Executive: Principal and Assistant Principal Evaluation Process, from http://www.ncpublic schools.org/docs/profdev/training/principal/evaluationproc ess.pdf, September 2, 2010. (Access date: 18 September 2010).

[12] General Assembly of North Carolina, S.L. 2007-517, 2007.

[13] E. Jones, “A Professional Practice Portfolio for Quality Learning”, Higher Education Quarterly, B. Blackwell, Oxford, UK, 2010, pp. 292-312.

[14] W. J. Popham, Everything School Leaders Need to Know About Assessment, Corwin, Thousand Oaks, CA, 2010, p. 135. 
[15] J.W. Beckstead, "Content Validity is Naught", International Journal of Nursing Studies, Pergamon Press, Oxford, UK, 2009, pp. 1274-1284.

[16] B. Huot, "Reliability, Validity, and Holistic Scoring: What We Know and What We Need to Know", College Composition and Communication, National Council of Teachers of English, Urbana, IL, 1990, pp. 201-213.

[17] D. Baume, and M. Yorke, "Reliability in Evaluating Portfolios for Higher Education Teacher Accreditation”, Academic Exchange Quarterly, Chattanooga State Technical Community College, Chattanooga, TN, 2001, pp.17-24.

[18] Waters, T., R.J. Marzano, and B. McNulty, McRel's Balanced Leadership Framework: Developing the Science of Educational Leadership, Mid-continent Research for Education and Learning, Aurora, CO, 2004, p. 7.

[19] E. Baker, P.E. Barton, L. Darling-Hammond, E. Haertel, H.F. Ladd, R.L. Linn, D. Ravitch, R. Rothstein, R.J. Shavelson, and L.A. Shepard, Problems with the Use of Student Test Scores to Evaluate Teachers, EPI Briefing Paper Number 278, Economic Policy Institute, NY, 29 August 2010.

[20]. Mid-Continent Research for Education and Learning, Final Report: Development, Field Test, and Validation Of The NC Educator Evaluation System, from http://www.ncptsc.org/EvaluationDocs/NCEES.htm, 2011. (Access date: 17 May 2011). 